\title{
BioMedicine
}

Volume 10 | Issue 1

Article 2

2020

\section{An immunohistochemical study of HER2 expression in primary brain tumors}

Follow this and additional works at: https://www.biomedicinej.com/biomedicine

Part of the Life Sciences Commons, and the Medical Sciences Commons (c) (i)

This work is licensed under a Creative Commons Attribution 4.0 License.

\section{Recommended Citation}

Ramezani, Mazaher; Siami, Shadi; Rezaei, Mansour; Khazaei, Sedigheh; and Sadeghi, Masoud (2020) "An immunohistochemical study of HER2 expression in primary brain tumors," BioMedicine: Vol. 10 : Iss. 1 , Article 2.

DOI: $10.37796 / 2211-8039.1001$

This Original Articles is brought to you for free and open access by BioMedicine. It has been accepted for inclusion in BioMedicine by an authorized editor of BioMedicine. 


\title{
An immunohistochemical study of HER2 expression in primary brain tumors
}

\author{
Mazaher Ramezani ${ }^{a}$, Shadi Siami ${ }^{b}$, Mansour Rezaei ${ }^{c}$, \\ Sedigheh Khazaei ${ }^{\text {, }}$ Masoud Sadeghi ${ }^{\mathrm{d}, *}$
}

\footnotetext{
${ }^{a}$ Molecular Pathology Research Center, Imam Reza Hospital, Kermanshah University of Medical Sciences, Kermanshah, Iran

b Students Research Committee, Kermanshah University of Medical Sciences, Kermanshah, Iran

${ }^{c}$ Departments of Biostatistics, Fertility and Infertility Research Center, Kermanshah University of Medical Sciences, Kermanshah, Iran

${ }^{\mathrm{d}}$ Medical Biology Research Center, Kermanshah University of Medical Sciences, Kermanshah, Iran
}

\begin{abstract}
Background: Primary brain tumors (PBTs) include any tumor in the brain whose prognosis is weak because of their histological characteristics.

Aim: Herein, this study aimed to assess the HER2 tumor marker frequency in PBTs.

Materials and methods: This study was done on the samples of primary brain tumor diagnosis from 2008 to 2015.

Results: Out of 107 patients of brain tumor that had a mean age of 40.4 years $(61.7 \%$ men), the most common location of the tumor was in the supratentorial region $(63.85 \%$ cases). The prevalence of high-grade astrocytoma (HGA) and lowgrade astrocytoma (LGA) at diagnosis was $43.9 \%$ and $37.4 \%$, respectively. With regard to HER2 score, HER2-positive (scores $2 \& 3$ ) was in $42.1 \%$ of patients. On the other hand, HER2-negative (-) was in $57.9 \%, 2+$ in $33.6 \%$, and $3+$ in $8.4 \%$ of patients. The patients of LGA had significantly younger ages, lower HER2 positivity, and lower HER2 percent compared with the HGA patients.

Conclusions: The type of brain tumors can impact on HER2 expression that high HER2 expression in HGA may be helpful for therapeutic aims. Further studies are required to support these results with a higher volume of patients in the world.
\end{abstract}

Keywords: HER2, immunohistochemistry, primary brain tumor

\section{Introduction}

$\mathbf{P}$ rimary brain tumors (PBTs) involve any tumors in the brain that can start from different parts of the brain [1-3]. Their prognosis is poor because of their histologic features; nevertheless, few benign tumors are determined in areas of inoperable $[4,5]$. In the studies reported in the U.S. and Europe, the incidence rate of brain neoplasms varies between 17.6 and 22 per 100,000 persons [6]. Around 18,500 new cases of PBTs are distinguished every year in the USA [7]. A systematic review in Iran from 2000 to 2010 reported PBTs had a total incidence of 2.74/100,000 persons, the most usual histopathologies of which included meningioma, glioblastoma multiforme (GBM), astrocytoma and ependymoma [8]. Astrocytic tumors as a type of PBTs may progress to GBM, a very malignant tumor of the central nervous system (CNS) [9-14]. Medulloblastoma is the most frequent malignant brain tumor in children (a peak incidence at ages 5-7 years) [15-19], accounting for around $20 \%$ of all primary CNS tumors [16]. Recent studies have suggested that aberrations of the human epidermal growth factor receptor 2 (HER2) may be involved in astrocytic brain tumors [20-22]. HER2 is a significant prognostic target for metastatic breast carcinoma therapy $[23,24]$. HER2 overexpression is shown in a rate of $20 \%-40 \%$ in solid tumors

Received 11 July 2019; accepted 18 August 2019.

Available online 28 March 2020

* Corresponding author at: Medical Biology Research Center, Kermanshah University of Medical Sciences, Kermanshah, Iran.

E-mail address: sadeghi_mbrc@yahoo.com (M. Sadeghi). 
and is usually correlated with a poor prognosis $[25,26]$. Trastuzumab (Herceptin) is the first antiHER2 therapy, especially in some metastatic/ advanced solid tumors (breast and gastroesophageal cancers) $[27,28]$ to be approved by the FDA for treatment of breast tumor [28-30]. The studies conducted in different areas on various ethnicities/races have indicated that HER2 can express in PBTs, whose expression depends on tumor location and tumor type $[15,16,23,31-34]$. Therefore, for the first time, we aimed to study the prevalence of HER2 marker in different types of PBTs in the West of Iran and Kurdish race.

\section{Materials and methods}

The Ethics Committee of Kermanshah University of Medical Sciences approved this study. This descriptive study was performed on the 107 samples diagnosed with the primary malignant brain tumor that they were received from the pathology laboratory of Imam Reza Hospital from 2008 to 2015.

\subsection{Immunohistochemistry}

Formalin-fixed paraffin-embedded tissue (FFPET) specimens from each previously diagnosed
PBT (based on the WHO classification) were cut into 4 micron-thick specimens and placed on glass slides. These specimens were stained by hematoxylin and eosin staining. The initial diagnosis was confirmed by the pathologist. Then, new specimens were provided, and immunohistochemistry (IHC) staining was done. Primary antihuman antibody against HER2 (c-erbB-2) oncoprotein (DAKO Diagnostics, Polyclonal Rabbit Anti-Human c-erbB-2 oncoprotein, Code A0485) was applied by the IHC method according to the manufacturer's brochure. Only staining of the cell membrane was considered specific for c-erbB-2 oncoprotein. Positive control samples were received from strong c-erbB-2 stained breast carcinomas and negative ones from normal breast tissue. Brown color in tumor cell cytoplasmic membrane was considered c-erbB-2- positive. The staining intensity was graded from 0 to $3+$, as follows: no staining (0), low intensity and incomplete membrane staining $(<10 \%$ of cells) $(1+)$, low intensity and complete membrane staining $(>10 \%$ of cells) (2+), and high intensity and complete membrane staining $(>10 \%$ of cells) $(3+)$. Tumors with scores 0 and $1+$ were evaluated negatively, while those with scores $2+$ and $3+$ were evaluated positively [35]. Fig. 1 is shown IHC staining pattern of $0-3+$ in pilocytic and anaplastic astrocytomas.
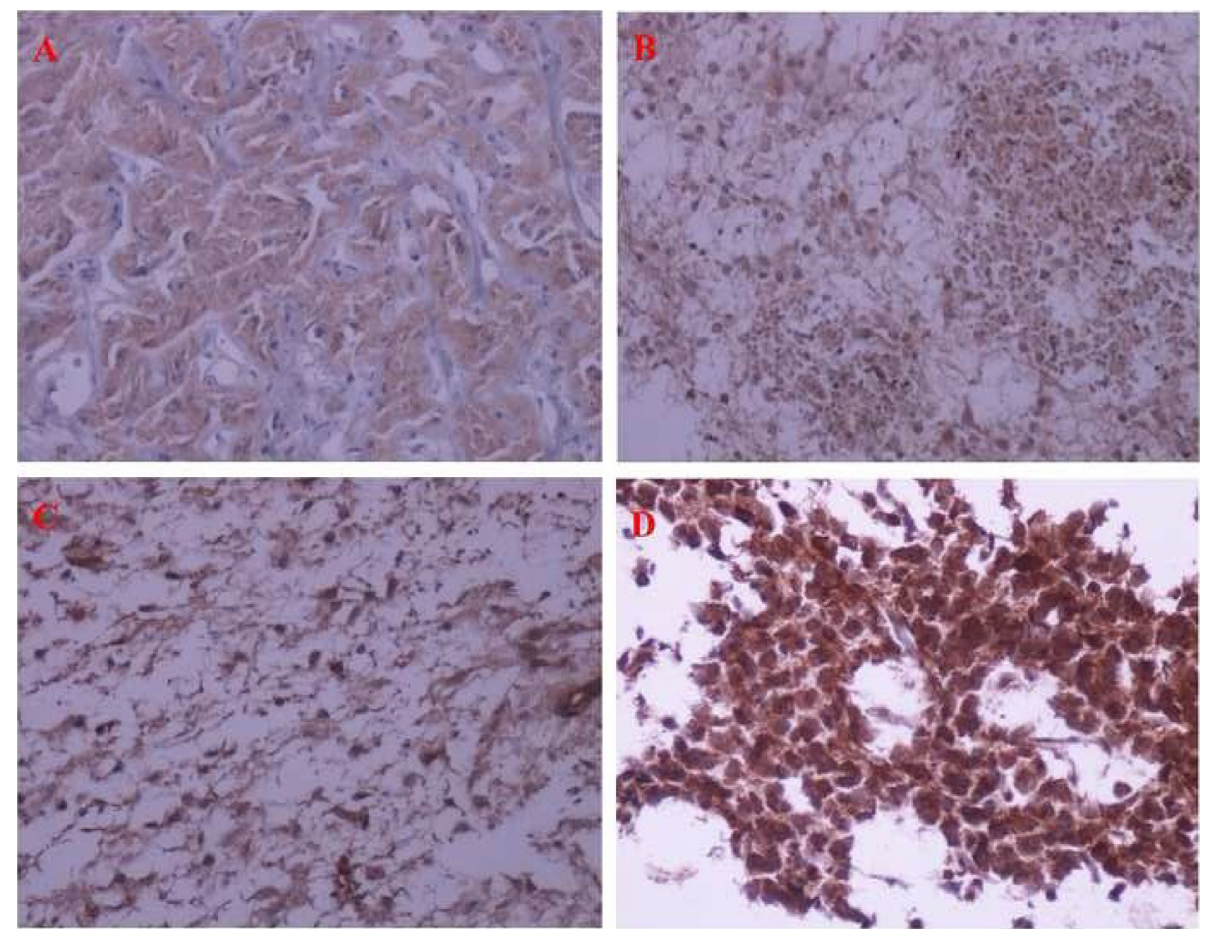

Fig. 1. Immunohistochemistry staining of HER2, $\times 200$ magnification: A) Pilocytic astrocytoma (score = 0), B) Pilocytic astrocytoma (score $=1$ ), C) Pilocytic astrocytoma (score = 2), and D) Anaplastic astrocytoma (score =3). 


\subsection{Statistical analysis}

The data analysis was performed by SPSS version 16 software. The mean and standard deviation were computed for age; whereas, the number of patients and percentage were considered for the other data. Chi-square test was used for comparison of age between the factors and t-test for others among the variables.

\subsection{Limitations}

1) Losing the information from some patients.

2) Unavailability of some paraffin blocks.

3) A low number of cases in the Hospital.

4) Lack of fluorescence in situ hybridization (FISH) for HER2 (2+).

\section{Results}

Out of 107 patients with PBTs with a mean age at diagnosis of 40.4 years (range, $1-88$ years), $61.7 \%$ of patients were male. Reporting tumor location in 85

Table 1. Baseline characteristics of the patients with primary brain tumors $(n=107)$.

\begin{tabular}{|c|c|c|c|}
\hline Variable & $\mathrm{N}(\%)$ & Variable & $\mathrm{N}(\%)$ \\
\hline Age, year & & HER2 score & \\
\hline Mean $\pm S D$ & $40.4 \pm 22.35$ & 0 & $6(5.6)$ \\
\hline \multirow[t]{3}{*}{ Range } & $1-88$ & 1 & $56(52.3)$ \\
\hline & & 2 & $36(33.6)$ \\
\hline & & 3 & $9(8.4)$ \\
\hline Sex & & HER2 status & \\
\hline Male & $66(61.7)$ & Negative & $62(57.9)$ \\
\hline Female & $41(38.3)$ & Positive & $45(42.1)$ \\
\hline Tumor location & & HER2, \% & \\
\hline Sellar & $2(2.4)$ & Mean \pm SD & $55.31 \pm 28.15$ \\
\hline Supratentorial & $63(74.1)$ & Range & $0-100$ \\
\hline Brain stem & $3(3.5)$ & & \\
\hline Cerebellum & $17(20)$ & & \\
\hline NA & 22 & & \\
\hline Complaints & & HER2, \% & \\
\hline Lateralized & $18(30)$ & $\leq 10(-)$ & $6(5.6)$ \\
\hline Generalized & $22(36.7)$ & $11-50(+)$ & $43(40.2)$ \\
\hline Mixed & $20(33.3)$ & $\geq 51(++)$ & $58(54.2)$ \\
\hline NA & 47 & & \\
\hline \multicolumn{4}{|l|}{ Tumor type } \\
\hline LGA & $40(37.4)$ & & \\
\hline HGA & 47 (43.9) & & \\
\hline $\begin{array}{l}\text { Mixed } \\
\text { oligoastrocytoma }\end{array}$ & $1(0.9)$ & & \\
\hline PNET-SRCTLM & 17 (15.9) & & \\
\hline Hemangioblastoma & $1(0.9)$ & & \\
\hline $\begin{array}{l}\text { Choroid plexus } \\
\text { papilloma }\end{array}$ & $1(0.9)$ & & \\
\hline
\end{tabular}

Abbreviations: PNET-SRCTLM, Primitive neuroectodermal tumor small round cell tumor lymphoma medulloblastoma; LGA, Low-grade astrocytoma; HGA, High-grade astrocytoma; SD, Standard deviation; NA, Not available. patients, $74.1 \%$ of tumors occurred in the supratentorial region. The characteristics of the patients are shown in Table 1 . The prevalence of high-grade astrocytoma (HGA) and low-grade astrocytoma (LGA) at diagnosis was $43.9 \%$ and $37.4 \%$, respectively, primitive neuroectodermal tumor small round cell tumor lymphoma medulloblastoma $(15.9 \%)$, mixed oligoastrocytoma $(0.9 \%)$, hemangioblastoma $(0.9 \%)$, and choroid plexus papilloma $(0.9 \%)$. Checking HER2 scores, HER2-positive (scores $2 \& 3$ ) was in $42.1 \%$ of patients. On the other hand, HER2-negative $(-)$ was in $57.9 \%, 2+$ in $33.6 \%$, and $3+$ in $8.4 \%$ of patients.

Table 2 shows the correlation between some variables and HER2 status. There was no significant difference in age, sex, the tumor location, and the type of tumor between HER2-positive and HER2negative patients.

The correlation between some variables and HER2 status demonstrated no significant difference in the variables (age, sex, the tumor location, and the type of tumor) between HER2 (-), HER2 (2+), and HER2 (3+) samples (Table 3).

Fig. 2 illustrates the subtypes and tumor locations of PBTs more specifically. LGA II/IV (33 patients) and GBM grade IV/IV (30 patients) had the highest prevalence. In addition, parietal lobe, frontal lobe, and cerebellum with 21, 18, and 17 patients, respectively, had the highest prevalence.

Comparing the correlation between some variables among LGA and HGA, there was a significant

Table 2. The correlation between variables and HER2 status in the brain tumor patients $(n=107)$.

\begin{tabular}{llll}
\hline Variable & $\begin{array}{l}\text { HER2- } \\
\text { positive }\end{array}$ & $\begin{array}{l}\text { HER2- } \\
\text { negative }\end{array}$ & $P$-value \\
\hline $\begin{array}{l}\text { Age, year } \\
\quad \text { Mean } \pm \text { SD }\end{array}$ & $41.44 \pm 22.89$ & $39.02 \pm 22.09$ & 0.582 \\
$\begin{array}{l}\text { Sex } \\
\quad \text { Male }\end{array}$ & $27(60 \%)$ & $39(62.9 \%)$ & 0.458 \\
$\quad$ Female & $18(40 \%)$ & $23(27.1 \%)$ & \\
Tumor location $(\mathrm{n}=85)$ & & & \\
$\quad$ Sellar & $1(2.6 \%)$ & $1(2.2 \%)$ & \\
Supratentorial & $30(76.9 \%)$ & $33(71.7 \%)$ & \\
$\quad$ Brain stem & $1(2.6 \%)$ & $2(4.3 \%)$ & \\
$\quad$ Cerebellum & $7(17.9 \%)$ & $10(21.7 \%)$ & 0.934 \\
Tumor type & & & \\
$\quad$ LGA & $12(26.7)$ & $28(45.2 \%)$ & \\
$\quad$ HGA & $25(55.6 \%)$ & $22(35.5 \%)$ & \\
$\quad$ Mixed oligoastrocytoma & $0(0 \%)$ & $1(1.6 \%)$ & \\
PNET- SRCTLM & $7(15.6 \%)$ & $10(16.1 \%)$ & 0.179 \\
$\quad$ Hemangioblastoma & $0(0 \%)$ & $1(1.6 \%)$ & \\
$\quad$ Choroid plexus papilloma & $1(2.2 \%)$ & $0(0 \%)$ & \\
\hline
\end{tabular}

Abbreviation: PNET-SRCTLM, primitive neuroectodermal tumor small round cell tumor lymphoma medulloblastoma; LGA, Lowgrade astrocytoma; HGA, High-grade astrocytoma; SD, Standard deviation. 
Table 3. Correlation between study variables and HER2 status in the brain tumor patients $(n=107)$.

\begin{tabular}{|c|c|c|c|c|}
\hline Variable & $\operatorname{HER} 2(-)$ & HER2 (2+) & HER2 $(3+)$ & $P$-value \\
\hline Age, year & & & & 0.843 \\
\hline Mean \pm SD & $39.0 \pm 22.1$ & $41.1 \pm 20.8$ & $42.8 \pm 31.2$ & \\
\hline Sex & $39(62.9 \%)$ & $24(66.7 \%)$ & $6(66.7 \%)$ & 0.176 \\
\hline Male Female & $23(37.1 \%)$ & $12(33.3 \%)$ & $3(33.3 \%)$ & \\
\hline Tumor location $(\mathrm{n}=85)$ & & & & 0.865 \\
\hline Sellar & $1(2.2 \%)$ & $1(3.3 \%)$ & $0(0 \%)$ & \\
\hline Supratentorial & $33(71.7 \%)$ & $24(80 \%)$ & $6(66.7 \%)$ & \\
\hline Brain stem & $2(4.3 \%)$ & $1(3.3 \%)$ & $0(0 \%)$ & \\
\hline Cerebellum & $10(21.7 \%)$ & $4(13.3 \%)$ & $3(33.3 \%)$ & \\
\hline Tumor type & & & & 0.052 \\
\hline LGA & $28(45.2 \%)$ & $11(30.6 \%)$ & $1(11.1 \%)$ & \\
\hline HGA & $22(35.5 \%)$ & $20(55.6 \%)$ & $5(55.6 \%)$ & \\
\hline Mixed oligoastrocytoma & $1(1.6 \%)$ & $0(0 \%)$ & $0(0 \%)$ & \\
\hline PNET- SRCTLM & $10(16.1 \%)$ & $5(13.8 \%)$ & $2(22.2 \%)$ & \\
\hline Hemangioblastoma & $1(1.6 \%)$ & $0(0 \%)$ & $0(0 \%)$ & \\
\hline Choroid plexus papilloma & $0(0 \%)$ & $0(0 \%)$ & $1(11.1 \%)$ & \\
\hline
\end{tabular}

Abbreviation: PNET-SRCTLM, primitive neuroectodermal tumor small round cell tumor lymphoma medulloblastoma, LGA, Low-grade astrocytoma; HGA, High-grade astrocytoma; SD, Standard deviation.
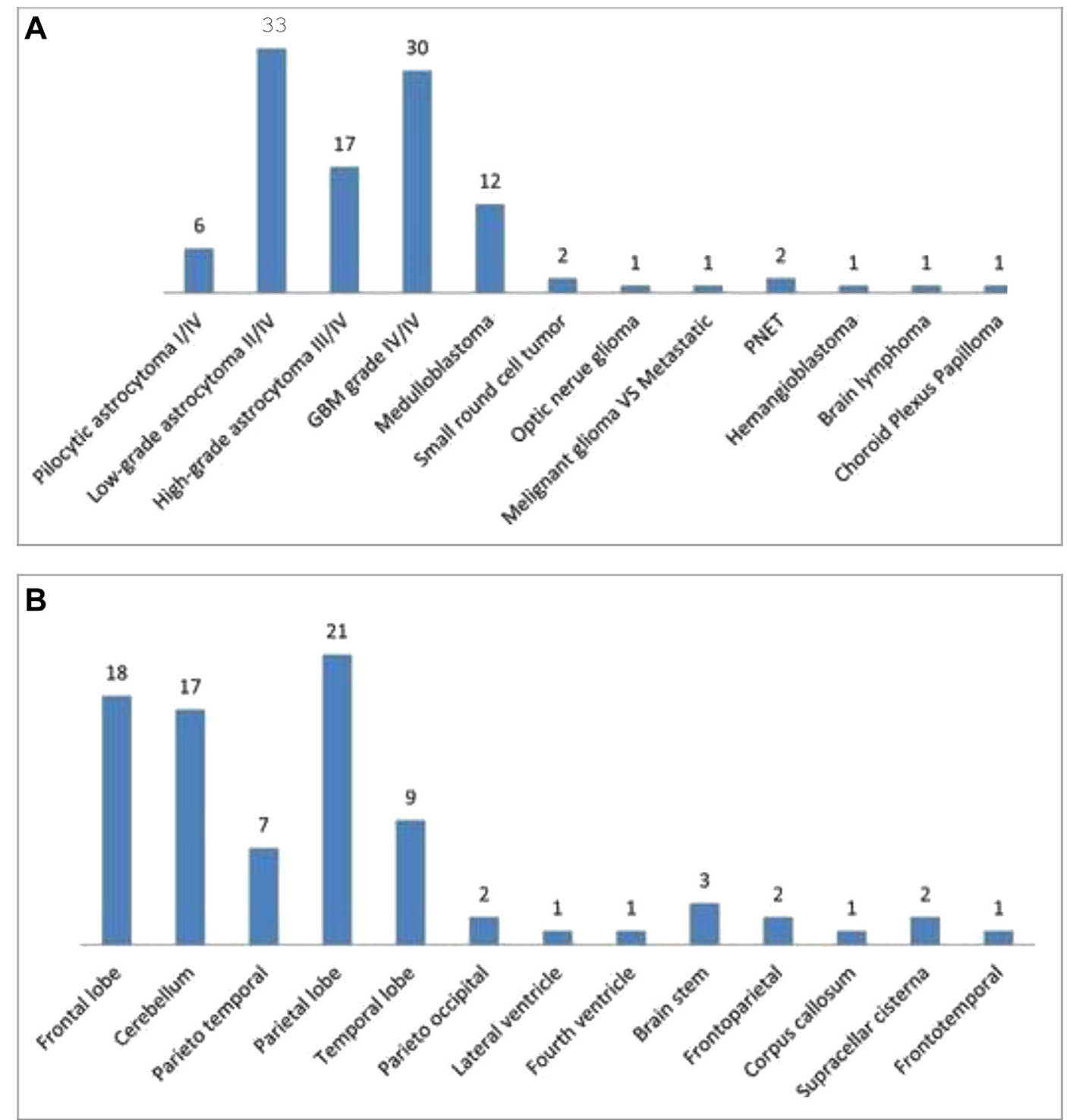

Fig. 2. Prevalence of the patients with primary brain tumors, (A) subtypes and (B) tumor locations. 
Table 4. Correlation between study variables and astrocytic tumors in the brain tumor patients $(n=87)$.

\begin{tabular}{|c|c|c|c|}
\hline Variable & $\begin{array}{l}\text { Low-grade } \\
\text { astrocytoma }\end{array}$ & $\begin{array}{l}\text { High-grade } \\
\text { astrocytoma }\end{array}$ & $P$-value \\
\hline Age, year & & & $<0.001$ \\
\hline Mean \pm SD & $35.6 \pm 20.6$ & $50.8 \pm 16.2$ & \\
\hline $\begin{array}{l}\text { Sex } \\
\text { Male }\end{array}$ & $24(60 \%)$ & $31(66 \%)$ & 0.362 \\
\hline Female & $16(40 \%)$ & $16(34 \%)$ & \\
\hline $\begin{array}{l}\text { Tumor location }(\mathrm{n}=67) \\
\text { Sellar }\end{array}$ & $2(7.1 \%)$ & $0(0 \%)$ & 0.012 \\
\hline Supratentorial & $21(75 \%)$ & $39(100 \%)$ & \\
\hline Brain stem & $1(3.6 \%)$ & $0(0 \%)$ & \\
\hline Cerebellum & $4(14.3 \%)$ & $0(0 \%)$ & \\
\hline $\begin{array}{l}\text { Her2 status } \\
\text { Negative }\end{array}$ & $28(70 \%)$ & $22(46.8 \%)$ & 0.024 \\
\hline Positive & $12(30 \%)$ & $25(53.2 \%)$ & \\
\hline $\begin{array}{l}\text { HER2, } \% \\
\quad \text { Mean } \pm \text { SD }\end{array}$ & $42.4 \pm 28.1$ & $65.4 \pm 24.6$ & $<0.001$ \\
\hline Range & $0-100$ & $5-100$ & \\
\hline $\begin{array}{l}\text { HER2, \% } \\
\quad \leq 10(-)\end{array}$ & $4(10 \%)$ & $1(2.1 \%)$ & 0.006 \\
\hline $11-50(+)$ & $22(55 \%)$ & $14(29.8 \%)$ & \\
\hline$\geq 51(++)$ & $14(35 \%)$ & $32(68.1 \%)$ & \\
\hline
\end{tabular}

Abbreviation: SD, Standard deviation.

difference between the two astrocytomas in the variables of age, tumor location, HER2 status, and percentages (Table 4). The HGA patients had significantly an older age, higher HER2 positivity, and higher HER2 percentage compared with the LGA patients $(P<0.05)$. In addition, all HGA tumors were in the supratentorial region compared with $75 \%$ of LGA tumors in this location $(P=0.012)$.

\section{Discussion}

The present study analyzed HER2 expression in PBTs. The results showed that $42.1 \%$ of the patients were HER2-positive. In addition, $33.6 \%$ and $8.4 \%$ of tumors in the patients were HER2 $2+$ and $3+$, respectively. In the comparison of LGA versus HGA, HER2 positivity in HGA tumors was significantly higher than LGA tumors.

One study [35] investigated seventy-two cases with LGA and HGA $(56.9 \%$ GBMs, $13.9 \%$ diffuse astrocytomas, and $20.8 \%$ anaplastic astrocytomas) for HER2 overexpression, whose results showed $23.6 \%$ of patients were HER2-positive. There was no HER2 positivity in diffuse astrocytoma and pilocytic astrocytoma specimens, and overexpression was identified just for GBM subtype. In Reszeć's study [9] on sixty-five patients with astrocytic tumors, including 17 diffuse astrocytomas, 23 anaplastic astrocytomas, and $25 \mathrm{GBMs}$, HER2 expression was observed in $88.3 \%, 88 \%$, and $82.6 \%$ of diffuse astrocytoma, anaplastic astrocytoma, and GBM, respectively. In GBM, 11 samples $(47.8 \%)$ were $(+)$ positive and only $8(34.8 \%)$ tumors were $(++)$ positive. In 11/22 medulloblastoma tumors, $10 \%-50 \%$ of the tumors showed HER2 and HER4 positivity, which were detectable only in high-grade glial tumors [36]. Torp et al. [21] found HER2 positivity in 9 of 21 GBM tumors $(43 \%)$.

A study [37] included 44 GBM patients (61.4\% males) with a mean age of 79 years. All tumors were HER2 negativity by IHC and also amplification by FISH. Happasalo et al. [20] confirmed this result with astrocytic neoplasms. Meurer et al. [31] analyzed 40 medulloblastoma tumors and found that HER2 was positive in 23 patients $(57.5 \%)$. In a retrospective study [32] on 57 and 16 cases with GBM and grade III gliomas, respectively, all GBM tumors expressed HER2 $(2+$ and $3+$ ) highly and all secondary GBM tumors with low intensity ( 0 and $1+)$. A series of 70 cases with childhood medulloblastoma were analyzed for HER2 expression by IHC, sixty of which $(85.7 \%)$ were found to be positive in IHC analysis. Ahmed et al. [15] showed a $40 \%$ HER2 expression in medulloblastomas. Out of 149 GBM cases $(54.4 \%$ males and the mean age of 64 years); HER2 overexpression was found in 23 cases (15.4\%) [23]. Potti et al. [38] checked 347 adult patients (the mean age of 53 years with $55.6 \%$ males) with PBTs. It was detected that $10.4 \%$ of the archival pathologic samples identified the presence of HER2 overexpression by the IHC.

Gulati et al. [33] investigated HER2 expression in 31 cases with anaplastic astrocytomas with three monoclonal antibodies, including CB11, 3B5, and 5A2. HER2 positivity was observed in $45 \%, 100 \%$, and $52 \%$ of cases, respectively. This discrepancy in results may be due to using different monoclonal antibodies and different interpretations of the positive samples. One study [32] showed better survival with low HER2 expression in patients with medulloblastoma tumors. Koka et al. [23], after age, smoking history, performance status, and treatment adjusting of GBM patients, revealed that HER2 overexpression significantly raised the early mortality odds (the median survival of patients for HER2 overexpression was four months compared to eight months for lack of overexpression), which were confirmed by Potti et al. [38] Therefore, the results showed that overexpression of HER2 may be a weak prognostic marker in GBM cases [23] and astrocytic tumors of the brain [36].

The studies suggested that HER2 expression may be included in the development and progression of astrocytic brain tumors and may be potentially important due to the role of Herceptin therapy in these tumors $[16,39,40]$. 


\section{Conclusions}

Considering the high expression of HER2 in most brain tumors, overexpression of HER2 may be a weak prognostic marker in patients with PBTs. But the results showed the type of brain tumors can impact on HER2 expression and high expression in HGA may be helpful for therapeutic aims. Further studies are recommended to be conducted on a more number of patients in various areas to confirm these results.

\section{Acknowledgments}

This article partially fulfills the requirements for the degree of general medicine by Shadi Siami at Kermanshah University of Medical Sciences, Kermanshah, Iran. The authors would like to thank the Clinical Research Development Center of Imam Reza Hospital for Consulting Services.

\section{Funding}

The financial support of the Research Council of Kermanshah University of Medical Sciences is highly acknowledged (Grant Number: 94547).

\section{Conflict of Interest}

None.

\section{References}

[1] Fritz A, Percy C, Jack A, Shanmugaratnam K, Sobin L, Parkin DM, et al. International classification of diseases for oncology. 3rd ed. Geneva: World Health Organizatiol; 2000.

[2] Perkins A, Liu G. Primary brain tumors in adults: diagnosis and treatment. Am Fam Physician 2016;93:211-7.

[3] de Robles P, Fiest KM, Frolkis AD, Pringsheim T. Atta C1, St Germaine-Smith C, et al. The worldwide incidence and prevalence of primary brain tumors: a systematic review and meta- analysis. Neuro Oncol 2015;17:776-83.

[4] Dho YS, Jung KW, Ha J, Seo Y, Park CK, Won YJ, et al. An updated nationwide epidemiology of primary brain tumors in Republic of Korea. Brain Tumor Res Treat 2013;2017(5): $16-23$.

[5] Xiong L, Wang F, Qi Xie X. Advanced treatment in highgrade gliomas. J BUON 2019;24:424-30.

[6] Ostrom QT, Gittleman H, Fulop J, Liu M, Blanda R, Kromer C, et al. CBTRUS statistical report: primary brain and central nervous system tumors diagnosed in the United States in 2008-2012. Neuro Oncol 2015;17:iv1-62.

[7] American Cancer Society. Cancer facts and figures. Available online: http://www.cancer.org. Last accessed April 15th 2017.

[8] Jazayeri SB, Rahimi-Movaghar V, Shokraneh F, Saadat S, Ramezani R. Epidemiology of primary CNS tumors in Iran: a systematic review. Asian Pac J Cancer Prev APJCP 2013;14: 3979-85.

[9] Reszeć J, Bernaczyk PS, Milewski R, Chyczewski L, Mariak Z. c-erbB-2 protein expression in astrocytic tumors of the brain. Med Sci Mon Int Med J Exp Clin Res 2011;17:BR216-20.

[10] Huang X, Bai HM, Chen L, Li B, Lu YC. Reduced expression of LC3B-II and Beclin 1 in glioblastoma multiforme indicates a down-regulated autophagic capacity that relates to the progression of astrocytic tumors. J Clin Neurosci 2010;17: 1515-9.

[11] Park SH, Won J, Kim SI, Lee Y, Park CK, Kim SK, et al. Molecular testing of brain tumor. J Pathol Transl Med 2017; 51:205-23.

[12] Masiulionytè B, Valiulytè I, Tamašauskas A, Skiriutè D. Metallothionein genes are highly expressed in malignant astrocytomas and associated with patient survival. Sci Rep 2019;9:5406.

[13] Néant I, Haiech J, Kilhoffer MC, Aulestia FJ, Moreau M, Leclerc C. Ca2+-Dependent transcriptional repressors KCNIP and regulation of prognosis genes in glioblastoma. Front Mol Neurosci 2018;11:472.

[14] Ding Y, Yu S, Bao Z, Liu Y, Liang T. CDC20 with malignant progression and poor prognosis of astrocytoma revealed by analysis on gene expression. J Neuro Oncol 2017;133:87-95.

[15] Ahmed N, Ratnayake M, Savoldo B, Perlaky L, Dotti G, Wels WS, et al. Regression of experimental medulloblastoma following transfer of HER2-specific T cells. Canc Res 2007;67: 5957-64.

[16] Gajjar A, Hernan R, Kocak M, Fuller C, Lee Y, McKinnon PJ, et al. Clinical, histopathologic, and molecular markers of prognosis: toward a new disease risk stratification system for medulloblastoma. J Clin Oncol 2004;22:984-93.

[17] Robson JP, Remke M2, Kool M, Julian E, Korshunov A, Pfister SM, et al. Identification of CD24 as a marker of Patched1 deleted medulloblastoma-initiating neural progenitor cells. PloS One 2019;14. e0210665.

[18] Kahn SA, Wang X, Nitta RT, Gholamin S, Theruvath J, Hutter G, et al. Notch1 regulates the initiation of metastasis and self-renewal of Group 3 medulloblastoma. Nat Commun 2018;9:4121.

[19] Salehpour F, Mirzaei F, Meshkini A, Parsay S, Salehi S, Asl MMB. Trends in primary brain tumors: a 5-year retrospective histologically confirmed study in tabriz, Iran, 20112016. Asian J Neurosurg 2019;14:427-31.

[20] Haapasalo H, Hyytinen E, Sallinen P, Helin H, Kallioniemi OP, Isola J. c-erbB-2 in astrocytomas: infrequent overexpression by immunohistochemistry and absence of gene amplification by fluorescence in situ hybridization. Br J Canc 1996;73:620-3.

[21] Torp SH, Gulati S, Johannessen E, Dalen A. Coexpression of cerbB 1-4 receptor proteins in human glioblastomas. An immunohistochemical study. J Exp Clin Canc Res 2007;26:353-9.

[22] Bazley LA, Gullick WJ. The epidermal growth factor receptor family. Endocr Relat Canc 2005;12:S17-27.

[23] Koka V, Potti A, Forseen SE, Pervez H, Fraiman GN, Koch M, et al. Role of Her-2/neu overexpression and clinical determinants of early mortality in glioblastoma multiforme. Am J Clin Oncol 2003;26:332-5.

[24] Lei L, Ye WW, Zheng LF, Huang P, Shi L, Huang J, et al. A significant response to a combination of trastuzumab and vinorelbine in HER2-negative metastatic breast cancer with HER2 V777L mutation. OncoTargets Ther 2019;12:2931-6.

[25] Pritchard KI, O'Malley FA, Andrulis I, Shepherd LE, Tu D, Levine MN, et al. Prognostic and predictive value of HER2/ neu in a randomized trial comparing $\mathrm{CMF}$ to $\mathrm{CEF}$ in premenopausal women with axillary node-positive breast cancer (NCIC CTG MA.5) (abstract). Proc Am Soc Clin Oncol 2002;21:42A.

[26] Blackwell KL, Burstein HJ, Storniolo AM, Rugo H, Sledge G, Koehler M, et al. Randomized study of Lapatinib alone or in combination with trastuzumab in women with ErbB2-positive, trastuzumab-refractory metastatic breast cancer. J Clin Oncol 2010;28:1124-30.

[27] Müller V, Clemens M, Jassem J, Al-Sakaff N, Auclair P, Nüesch E, et al. Long-term trastuzumab (Herceptin $\mathbb{R}$ ) treatment in a continuation study of patients with HER2positive breast cancer or HER2-positive gastric cancer. BMC Canc 2018; 18:295.

[28] Pondé N, Wildiers H, Awada A, de Azambuja E, Deliens C, Lago LD. Targeted therapy for breast cancer in older patients. J Geriatr Oncol 2019;S1879-4068(18):30514-9. pii. 
[29] Noonberg SB, Benz CC. Tyrosine kinase inhibitors targeted to the epidermal growth factor receptor subfamily: role as anticancer agents. Drugs 2000;59:753-67.

[30] Figueroa-Magalhães MC, Jelovac D, Connolly R, Wolff AC. Treatment of HER2-positive breast cancer. Breast 2014;23: 128-36.

[31] Meurer RT, Martins DT, Hilbig A, Ribeiro MdC, Roehe AV, Barbosa-Coutinho LM, et al. Immunohistochemical expression of markers Ki-67, neun, synaptophysin, p53 and HER2 in medulloblastoma and its correlation with clinicopathological parameters. Arq Neuropsiquiatr 2008;66:385-90.

[32] Mineo JF, Bordron A, Baroncini M, Maurage CA, Ramirez C, Siminski R-M, et al. Low HER2-expressing glioblastomas are more often secondary to anaplastic transformation of lowgrade glioma. J Neuro Oncol 2007;85:281-7.

[33] Gulati S, Ytterhus B, Granli US, Gulati M, Lydersen S, Torp SH. Overexpression of c- erbB2 is a negative prognostic factor in anaplastic astrocytomas. Diagn Pathol 2010;5:18.

[34] Gilbertson RJ, Perry RH, Kelly PJ, Pearson AD, Lunec J. Prognostic significance of HER2 and HER4 coexpression in childhood medulloblastoma. Canc Res 1997;57:3272-80.

[35] Muallaoglu S, Besen AA, Ata A, Mertsoylu H, Arican A, Kayaselcuk F, et al. Lack of prognostic significance of C-
erbB-2 expression in low-and high-grade Astrocytomas. Asian Pac J Cancer Prev APJCP 2014;15:1333-7.

[36] Bodey B, Kaiser HE, Siegel SE. Epidermal growth factor receptor (EGFR) expression in childhood brain tumors. In Vivo 2005;19:931-41.

[37] Haynik DM, Roma AA, Prayson RA. HER-2/neu expression in glioblastoma multiforme. Appl Immunohistochem Mol Morphol 2007;15:56-8.

[38] Potti A, Forseen SE, Koka VK, Pervez H, Koch M, Fraiman G, et al. Determination of HER-2/neu overexpression and clinical predictors of survival in a cohort of 347 patients with primary malignant brain tumors. Canc Invest 2004;22:537-44.

[39] Duhem-Tonnelle $\mathrm{V}$, Bièche $\mathrm{I}$, Vacher $\mathrm{S}$, Loyens $\mathrm{A}$, Maurage CA, Collier F, et al. Differential distribution of erbB receptors in human glioblastoma multiforme: expression of erbB3 in CD133-positive putative cancer stem cells. J Neuropathol Exp Neurol 2010;69:606-22.

[40] Gao L, Li F, Dong B, Zhang J, Rao Y, Cong Y, et al. Inhibition of STAT3 and ErbB2 suppresses tumor growth, enhances radiosensitivity, and induces mitochondria-dependent apoptosis in glioma cells. Int J Radiat Oncol Biol Phys 2010;77:1223-31. 